\title{
EXPLORING THE INTERACTIONS ON AN ONLINE NARRATIVE WRITING PLATFORM
}

\author{
${ }^{1}$ Nagaletchimee Annamalai, ${ }^{2}$ Tan Kok Eng, ${ }^{3}$ Amelia Abdullah \\ \& ${ }^{4}$ Sorojini Sivagurunathan \\ ${ }^{1}$ School of Distance Education \\ ${ }^{2-3}$ School of Educational Studies \\ Universiti Sains Malaysia \\ ${ }^{4}$ Sekolah Menengah Kebangsaan Darul Ridzuan
}

${ }^{1}$ Corresponding author: nagalaxl@yahoo.com

\begin{abstract}
Purpose - This paper reports a study that investigated the interactions of six students learning to write narrative essays on an online narrative writing platform (ONWP). Participants were six students and a teacher from an urban Chinese Secondary School in the northern region of Malaysia.
\end{abstract}

Methodology - The qualitative data used in this study were online interaction archives and narrative essays collected from an ONWP used by the teacher to teach narrative writing. The student-teacher interactions were coded based on the categories related to cognitive, teaching and social presences as suggested by the Community of Inquiry Model (Garrison, Archer \& Anderson, 2000).

Findings - Findings indicated that the cognitive, teaching and social presences suggested by the CoI model were present in the interactions while students were engaged in the ONWP. However, certain descriptors of the CoI were not found in the study. The major contribution of this study is the single, dual and triple phases which emerged from this study. The essays' scores revealed that the students improved in their narrative writing ability after engaging in the ONWP.

Significance - The findings have placed the model in a new environment involving the application of CoI model in a Chinese Secondary School. Being online to fulfil wide-ranging tasks 
does not only involve critical thinking but also creative writing. Teachers involved in online teaching and learning activities need to encourage students to be involved in critical thinking. Students should also realise that there is more to learn in writing than just making corrections based on the comments.

Keywords: Online collaboration, CoI model, cognitive presence, social presence, teaching presence, social interactions, school writing

\section{INTRODUCTION}

The value added by ICT and Internet tools is contributed by the methods and the instruction in teaching and learning rather than the obsession with the tools. This points to the fact that the pedagogical applications of the tools with certain elements of learning are more important than the constant preoccupation with the tools of technology. Clark (2001) interestingly illustrates the above idea with an analogy of a delivery truck to explain his idea on instructional tools. He states that instructional tools are "mere vehicles that deliver instruction but do not influence students' achievement any more that the truck that delivers our groceries causes changes in our nutrition" (p. 2). Given this perspective, a logical deduction is that learning theory, pedagogical practices, and technology must be integrated concurrently to reap success in the teaching and learning environment. Bagley and Hunter (1992) termed the integration of these components a synergistic relationship.

It is worth noting that the Web 2.0 tools will keep evolving. For example, blogs have evolved from textual blogs and audio blogs to video blogs. Such is the evolutionary nature of the tools of technology. Even the present popular social networking tool such as Facebook will ultimately change to a newer platform. Though this study uses Facebook, it is not about Facebook. This study brings the students to a popular networking site to teach them narrative writing. Hence, what should be the concern of the educators is how the pedagogical practices can be meaningful while meeting the challenges of a newer technology. When the new social networking sites appear, the pedagogical practices and the learning theory that are suggested in this study can be considered on a newer platform. 
The pedagogical practices suggested in this study can also be used on platforms such as My Space, Google Docs, Bebo and newer platforms in the future.

The pedagogical practice in this study focuses on the Labov and Waletzky's (1967) narrative structure. Students are encouraged to interact with each other as underpinned by the constructivist theory. Both the presentation of the narrative structure and students' interactions are in the Facebook environment. The platform created in this study is known as Online Narrative Writing Platform (ONWP). The purpose of this study is to explore how students interact and learn narrative writing on the ONWP. The findings of this study are important to inform educators of plans and delivery methods in teaching and learning related to the use of ICT in teaching writing skills.

According to the Malaysian Education Blueprint (2013-2025) the Ministry has spent more than six million ringgit to encourage the use of Information Communication and Technology (ICT). It has been reported the use of ICT tools in the education context has not gone further than the use of word processing applications. The potential of ICT tools for the more engaging and interactive teaching and learning ways has not been utilized effectively. This signals the need for students and teachers to be familiarized with online teaching and learning activities that will encourage interaction, as well as the sharing of knowledge and ideas.

The ONWP innovatively created in this study, provides a new space for students to exchange ideas and opinions as well as to interact with their friends and teacher to improve their narrative writing. A full understanding of what and how the platform helps students in their narrative writing will require the examining of the online interactions, as well as the students' ability to write narrative essays before and after the interactions on the ONWP.

The participants' interactions were categorized based on the Community of Inquiry Model (2000). The CoI model as developed by Garrison, Archer and Anderson (2000) was used to study the interactions of the participants in the online learning environment (Facebook). The following question guided the current investigation: What are the presences and descriptors of the CoI model identified in this study? 


\section{LITERATURE REVIEW}

\section{Social Constructivism Theory}

Society and culture are the prime determinants of cognitive developments. Vygotsky (1978) strongly believes that learning cannot be separated from social and cultural contexts. The socio-cultural perspectives on learning see culture as the knowledge shared through interaction in a collaborative environment. Vygotsky explains that a child's cultural development appears twice: first between people (interpsychological) and then inside the child (intrapsychological). To understand the connection between development and learning we must differentiate the actual and potential levels of development. The actual stands for the achievement of a child independently. This is in contrast with the potential level of development which stresses on what learners can achieve when they work with others (Vygotsky 1978). According to Vygotsky this is termed as the Zone of Proximal Development.

The ONWP in the present study gave students the opportunity to interact and share their knowledge with others through their postings on the platform. The teacher and students were able to comment and give opinions. It was hoped that these comments contributed to the development of independence in thinking. In such a situation, possibilities are available for constructivist learning to take place and thinking occurs to discover new knowledge. This is precisely what the ONWP attempted to do in this study.

The next section details how the Labov and Waletzky's structures (1967) and CoI model are integrated based on the theory of social constructivism.

\section{Labov and Waletzky's Narrative Structures}

The teacher used the Labov and Waletzky's narrative structure(1967) to guide the students to write their essays in the ONWP created in Facebook. Labov and Waletzky's six-part narrative structure was strategically used in the online setting to make the essay writing tasks more relevant, purposeful and meaningful to students. It is a clear model that allows the formation of a more complex narrative. 
A number of studies (Babii \& Yazdanpanah, 2010; Stirling et al; 2007; Kigotho, 2002) found that students were able to write better after receiving instruction on the Labov and Waletzky's narrative structure. The structure, as given below, was uploaded on the ONWP by the teacher.
Abstract: What is the story about?
Orientation: Who, when, where, what?
Complicating Action: Then what happened?
Evaluation: So what, how is this interesting?
Result of resolution: What finally happened?
Coda: That's it. I've finished and am "bridging" back to our present situation.

The six stages offer information on the sort of linguistic forms that each stage typically takes. The systematically organized information helps students to write better and increases their awareness of the criteria for good narrative writing.

Vygotsky's emphasis on teacher's guidance at the initial stage was implemented in this study with the teacher guiding students on the Labov and Waletzky's narrative structure. Later with the guidelines students could expand their knowledge by producing an essay independently on their learner platform. After they had completed the individual essays, they interacted with their teacher and peers to improve the quality of the essays. It was hoped that students could write their narrative essays based on the Labov and Waletzky's narrative structure independently.

\section{Community of Inquiry Model}

Drawing on the constructivism theory, interaction is considered a crucial element in the students' learning experience. Interaction is the only way for individuals to make explicit certain ideas and processes that have been internalized in the minds of the individuals (Vygotsky, 1978). The learner's potential for intellectual growth is also enhanced with the help of scaffolding through interaction (Vygotsky, 1978). It is necessary to know how the interactions and the individual mental process take place in the online teaching and learning environment. 
One model that fits well with the constructivism theory is the Community of Inquiry (CoI) model by Garrison et al. (2000). The $\mathrm{CoI}$ model has been extensively used in the asynchronous learning environment to explain how students interact and learn together (Garrison et al. 2000). Researchers found that the CoI model is simple and applicable to illustrate interactions among online learners (Batruff \& Headley, 2009). The CoI model illustrates three overlapping presences; cognitive, teaching and social presences.

\section{Cognitive Presence}

Cognitive presence which is based on Dewey's (1916) critical reflection emphasizes that critical thinking is pertinent in deepening the meaning of student's experience and should be the base of the educational aim. Garrison et al. (2000) explain that cognitive presence which "reflects higher order knowledge acquisition and application" (p. 11) is grounded in the "critical-thinking literature" and "focuses on higher-order thinking processes" (p. 8). Lower order thinking skills in the CoI model refer to the triggering event and exploration phases. The higher order thinking skills refer to the integration and resolution phases. Table 1 illustrates the descriptors of cognitive presence.

The first category of cognitive presence refers to the feeling of uneasiness from an experience. This is termed as triggering event or communication. An issue or problem is identified from experience. The second phase is termed as exploration where there is a search for ideas, information and knowledge that gives meaning to the situation. At this stage, clarification occurs. The third stage is when one is combining information and knowledge in a logical way. The fourth stage is the resolution of the problem and application of the idea. Very briefly, cognitive presence as suggested by the CoI includes recognizing problems, exploration, construction, resolution and confirmation of understanding via interactions (Garrison et al., 2000). Cognitive presence as suggested by Garrison et al. includes an iterative and cyclical move through triggering event, exploration, integration and resolution phases. 


\section{Table 1}

\section{Descriptors of Cognitive Presence}

\begin{tabular}{lll}
\hline Descriptors & \multicolumn{1}{c}{ Indicators } & \multicolumn{1}{c}{ Socio-cognitive Processes } \\
\hline Triggering & Recognizing the & $\begin{array}{l}\text { Presenting background information that } \\
\text { culminates in a question }\end{array}$ \\
Event & problem & Evocative
\end{tabular}
Sense of Puzzlement Asking questions
Messages that take discussion in new direction

\section{Exploration}

\begin{tabular}{|c|c|c|}
\hline \multirow[t]{5}{*}{ Tentative } & $\begin{array}{l}\text { Divergence- } \\
\text { within the online } \\
\text { community }\end{array}$ & $\begin{array}{l}\text { Unsubstantiated contradiction of previous } \\
\text { ideas }\end{array}$ \\
\hline & $\begin{array}{l}\text { Divergence within a } \\
\text { single message }\end{array}$ & $\begin{array}{l}\text { Many different ideas/themes presented in } \\
\text { one message. }\end{array}$ \\
\hline & $\begin{array}{l}\text { Information } \\
\text { exchange }\end{array}$ & $\begin{array}{l}\text { Personal narratives/ descriptions/ facts (not } \\
\text { used evidence to support a conclusion) }\end{array}$ \\
\hline & $\begin{array}{l}\text { Suggestion for } \\
\text { consideration }\end{array}$ & $\begin{array}{l}\text { Author explicitly characterizes messages } \\
\text { exploration, e.g. "Does that seem about } \\
\text { right" "Am I way off the mark?" }\end{array}$ \\
\hline & Brainstorming & $\begin{array}{l}\text { Adds to established points but does not } \\
\text { systematically defend/ justify/ develop } \\
\text { addition }\end{array}$ \\
\hline
\end{tabular}

Leap to conclusion Offers unsupported opinions

\section{Integration}

Provisional

Convergence- among Reference to previous message by group members substantiated agreement, e.g. "I agree because..."

Convergence- within Justified developed, defensible, yet a single message tentative hypotheses

Connecting ideas, Integrating information from various synthesis sources- textbook, articles, personal experience

Creating solutions Explicit characterization of message as a solution by participant

Resolution

Resolution of the problem Application of the idea

Changes done by the students in the Written Assignments 
Some research indicates that the higher level of cognitive presence in the integration and resolution phases of the $\mathrm{CoI}$ model is seldom achieved (Luebeck \& Bice, 2005; Vaughan \& Garrison, 2005; Garrison et al., 2000). Archer (2010) explains that the researchers have been looking for the phases (integration and resolution phases) at the wrong place and students would probably reserve the integration and resolution phases in their assessments. There are possibilities to observe the higher phases in essay writing in undergraduate settings. This is supported by Garrison and Arbaugh (2007) who state there is a need to find more "evidence of integration and resolution stages of cognitive presence in documents such as case studies, papers and projects" (p. 171). The resolution phase in this study was carried out individually and was reflected in their final essays. Grades were given for individual essays.

Although there is a huge amount of literature that provides direction and understanding of the strengths and weaknesses of the CoI model, more research is needed in different settings (Shea, Hayes \& Vickers 2010; Archer 2010; Toth, Amrein-Beardsley \& Fougler, 2010). As such, it is important to investigate what is taking place when the CoI model is used in the Malaysian context.

\section{Teaching Presence}

Teaching presence is necessary in stabilizing the cognitive and social issues in the educational environment (Garrison et al., 2000). There is a large body of evidence confirming the importance of teaching presence for a successful online learning environment(Garrison \& Cleveland-Innes, 2005). Teaching presence is seen to encourage students to respond to the task given regularly, demonstrating effective online interaction. Without teaching presence the students will only be engaged in serial monologues (Pawan, Paulus, Yalchin \& Ching, 2003).

\section{Social Presence}

Social presence is viewed as a mediator between teaching and cognitive presences. It is recognised for its potential to encourage or hinder cognitive presence (Garrison, Cleveland \& Fung, 2010). It affects the learners' participation, interactions and engagement 
on the online learning environment and eventually influences their performance (Kear, 2010). The descriptors for teaching and cognitive presences were illustrated in the data analysis.

\section{METHODOLOGY}

This research was more keen to discover and interpret the discourse of the participants rather than test hypotheses using scores. For these reasons, a qualitative case study research design was deemed appropriate to explore the use of the ONWP. Due to its inductive nature, the outcome of the qualitative analysis will be able to provide rich data describing the phenomena studied (Patton, 2002).

A simple quantitative description was included for the total number of online interactions and the scores for their written assignments. Pope (2000) has rightly pointed out that a qualitative approach does not intend to quantify data. Simple counts are sometimes used and may provide a useful summary of some aspects of the analysis. It is wise to combine qualitative data with a simple quantitative summary to condense the findings (Seale, 1999).

\section{Participants}

The size of the group (number of students) is important to reach optimum performance from each of the students. It is best for students to work in small groups for better cohesion, intimacy, safety and trust (Perez-Sabater \& Rising 2009). Therefore, the number of participants was limited to six students and a teacher in this study. Six Secondary Four students were selected from an urban Chinese School in Penang. The students were 16 years old. The students had six years of exposure in learning English in the primary school and three years in the secondary school. Three students from the advanced and another three students from intermediate level were selected based on the PMR (Secondary Three) standardized public examination.

They were selected as a purposive sample based on the following criteria. They are able to access Facebook at home or in school, ii) volunteered to participate and iii) secured parental consent. One major reason why students agreed to participate in this study was 
because they felt that this would give them good practice to improve their narrative writing. The participants were given pseudonyms. The students were labelled as Deer Tommy, Valentini Belbo, Monster Kblue, Peonny Moon, Joyce Chee, Catelite Nina while the teacher was named Nanthini Maniam. The teacher participant was a teacher in the school where the research was carried out. The teacher participant was invited to implement the study on a voluntary basis. She was an experienced teacher and familiar with the expectations of the SPM examination (Secondary Five public examination).

Participants should be willing to participate voluntarily. For this reason, prior consent was obtained from parents and students as suggested by (Kaufman \&Kaufman, 2005). The Information Sheet explained the aims, the potential benefits of being involved in this study and the outcome of the research. The raters and coders also signed the consent form. The consent also made clear that there were no risks in taking part in the study. Anonymity assured that no information gathered and reported would refer to individuals or the school that provided the information.

\section{Procedures}

A closed group account was created to filter and control interactions by only inviting registered participants of this study for discussion. The teacher's tutor platform and the students' learner platform are on Facebook. On the tutor platform, teacher guided the students to write the narrative essays based on the Labov and Waletzky's narrative structure. The notion of scaffolding suggested by Vygotsky (1978) was made available by the teacher. Teacher further gave tips, suggestions on web-based materials, and examples of narrative essays (materials). Students were to write their individual essays on the learner platform. Materials and examples were given for Task 1 and Task 2 but not Task 3. It is hoped that for Task 3 students were able to work independently without any guidance from the teacher.

After completing their individual essays they were to interact online with their friends and teacher. After the interactions on the ONWP, students were to consider the comments given and improved the quality of the essays. In other words, they had to write two essays for the same title. The individual essays were placed on the tutor platform. Interactions took place on both the tutor platform and learner platform. 
There were a total of three writing tasks. Students were given two weeks to complete each task. Students took six weeks to complete the three tasks. The six students each wrote three essays before the interactions and wrote another three final essays after their interactions on the ONWP. Thirty six essays were collected for rating at the end of the research. Table 2 illustrates the schedule of the writing tasks.

Table 2

Schedule for the Writing Assignments

\begin{tabular}{cllll}
\hline Week & \multicolumn{1}{c}{ Task } & Platforms & & \\
\hline & $\begin{array}{l}\text { Tutor } \\
\text { Platform }\end{array}$ & $\begin{array}{l}\text { Learner } \\
\text { Platform }\end{array}$ & $\begin{array}{l}\text { Learner } \\
\text { Platform/ } \\
\text { Tutor Platform }\end{array}$ & $\begin{array}{l}\text { Learner } \\
\text { Platform }\end{array}$ \\
\hline Weeks 1-2 & $\begin{array}{l}\text { Task 1 } \\
\text { Title } \\
\text { Material 1 }\end{array}$ & First draft (1) & $\begin{array}{l}\text { Interaction on the } \\
\text { ONWP }\end{array}$ & Final draft (1) \\
& First Draft (2) & $\begin{array}{l}\text { Interaction on } \\
\text { the ONWP }\end{array}$ & Final draft (2) \\
\hline Weeks 3-4 & $\begin{array}{l}\text { Task 2 } \\
\text { Title } \\
\text { Material 2 }\end{array}$ & & First Draft (3) & $\begin{array}{l}\text { Interaction on } \\
\text { the ONWP }\end{array}$ \\
\hline Weeks 5-6 & $\begin{array}{l}\text { Task 3 } \\
\text { Title } \\
\text { No materials }\end{array}$ & & Final draft (3) \\
\hline
\end{tabular}

\section{Data Sources}

The participants' online interactions were printed out as a main source for analysis after the sixth week. The descriptors were given codes, for example, (CPA1, CPA2, CPA3). The online discussions were colour coded. Two coders were trained by the researchers to identify the three presences and the respective descriptors. Interrater reliability was obtained by using Cohen kappa procedures. The value for teaching presence was 0.8 , cognitive presence 0.7 and social presence 0.7 . The results were highly reliable. A third coder was employed as a 'tie breaker' if necessary. The participants' narrative essays were evaluated using the Tribble Assessment Scale (1996). The scores were averaged by three raters. If disagreements related to scores occurred consensus was reached through discussion. A flow chart for data collection is demonstrated in Figure 1. 


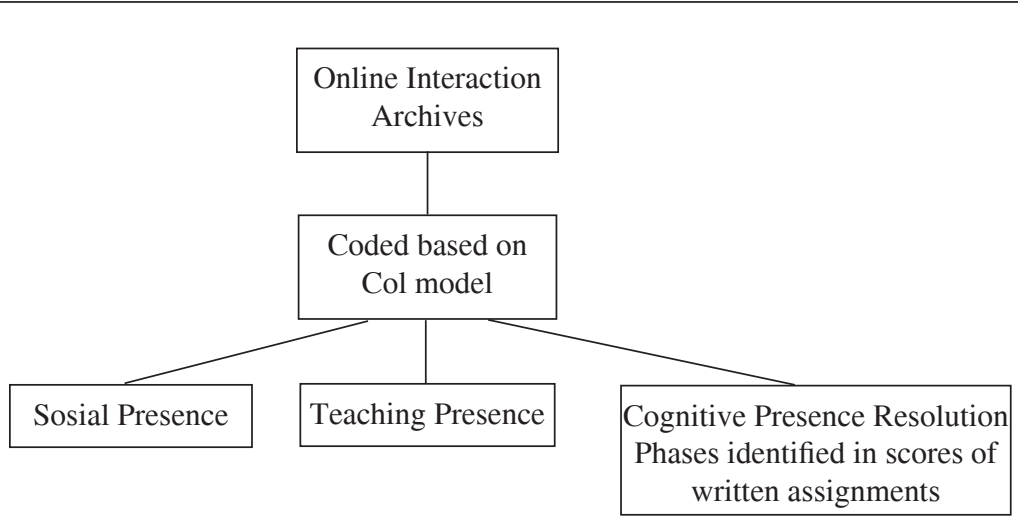

Figure 1. Flow Chart of Data Collection

\section{Findings and Discussion}

The discussion will be on the findings to the question: What are the presences and descriptors of the CoI model identified in this study? The participants were responsive and this was evident in their posts with a minimum of 8 comments and a maximum of 45 comments per week. The discussion below will begin with social presence. Table 3 illustrates examples of descriptors and sub categories of social presence (Annamalai \& Tan, 2014).

Table 3

Social Presence

\begin{tabular}{llllll}
\hline Codes & Descriptors & Task 1 & Task 2 & Task 3 & Total \\
\hline SPA & Affective & & & & \\
SPA1 & Expression of Emotions & 11 & 23 & 8 & $\mathbf{4 2}$ \\
SPA2 & Use of Humour & 11 & 8 & 5 & $\mathbf{2 4}$ \\
SPA3 & Self- Disclosure & 20 & 5 & 6 & $\mathbf{3 1}$ \\
SPB & Interactive & & & & \\
SPB1 & Continuing the Thread & - & - & - & - \\
SPB2 & Quoting for other messages & - & - & 1 & $\mathbf{1}$ \\
SPB3 & $\begin{array}{l}\text { Referring Explicitly to others } \\
\text { messages }\end{array}$ & - & - & - & - \\
SPB4 & Asking Questions & & & & \\
\hline
\end{tabular}




\begin{tabular}{llcccc}
\hline Codes & Descriptors & Task 1 & Task 2 & Task 3 & Total \\
\hline SPB5 & $\begin{array}{l}\text { Complementing, } \\
\text { Expressing Appreciation }\end{array}$ & 13 & 26 & 22 & 61 \\
SPB6 & $\begin{array}{l}\text { Expressing Agreement by name } \\
\text { SPC }\end{array}$ & 1 & 8 & 3 & $\mathbf{1 2}$ \\
Cohesive & Vocatives Addressing someone & N/A & N/A & N/A & N/A \\
SPC2 & $\begin{array}{l}\text { Addresses or refers to the group us- } \\
\text { ing inclusive pronouns }\end{array}$ & N/A & N/A & N/A & N/A \\
SPC3 & Phatics Salutations & 7 & 4 & - & $\mathbf{1 1}$ \\
\hline
\end{tabular}

The most number of interactions were related to the affective descriptor and the total was 97 followed by the interactive descriptor with 74 interactions and cohesive descriptor with 11 interactions. When comparing the sub-categories for the affective descriptor, expressions of emotions had the largest number of posts. There were no interactions related to 'continuing the thread'(SPB1) and 'referring explicitly to others' messages'(SPB3). Some of the sub-categories were not useful and were not coded for this study. Descriptors 'vocatives' (SPC1) and 'addresses or refer to the group elusive pronouns'(SPC2) were not useful and were not coded for this study.

\section{Teaching Presence}

Table 4 illustrates the number of occurrences for each descriptor of teaching presence.

Table 4

Numerical Distribution of Teaching Presence for Tasks 1, 2 and 3

\begin{tabular}{llcccc}
\hline Codes & \multicolumn{1}{c}{ Descriptors } & Task 1 & Task 2 & Task 3 & Total \\
\hline TPA & Instructional Design and Organization & & & & \\
TPA1 & Setting Curriculum & 1 & 1 & 2 & $\mathbf{4}$ \\
TPA2 & Designing Methods & - & - & - & - \\
TPA3 & Establishing Parameters & 1 & 2 & 1 & $\mathbf{4}$ \\
TPA4 & Utilizing medium Effectively & - & - & - & - \\
TPA5 & Establishing Netiquette & - & - & - & - \\
TPB & Facilitating Discourse & & & & \\
TPB1 & $\begin{array}{l}\text { Identifying Areas of Agreement and } \\
\text { Disagreement }\end{array}$ & 3 & - & - & $\mathbf{3}$ \\
\hline
\end{tabular}




\begin{tabular}{llcccc}
\hline Codes & \multicolumn{1}{c}{ Descriptors } & Task 1 & Task 2 & Task 3 & Total \\
\hline TPB2 & Seeking to reach consensus & - & - & - & - \\
TPB3 & $\begin{array}{l}\text { Encouraging, Acknowledging or } \\
\text { Reinforcing Students' Contribution }\end{array}$ & 13 & 14 & 5 & $\mathbf{3 2}$ \\
TPB4 & Setting Climate for Learning & - & - & - & - \\
TPB5 & $\begin{array}{l}\text { Drawing Participants and Prompting } \\
\text { Discussion }\end{array}$ & 1 & 7 & 10 & $\mathbf{1 8}$ \\
TPB6 & Assess the Efficacy of the Process & - & - & - & - \\
TPC & Direct Instruction & & & & \\
TPC1 & Present Content and Questions & - & - & - & - \\
TPC2 & Focus Discussion on Specific Issues & 5 & 9 & 3 & $\mathbf{1 7}$ \\
TPC3 & Summarize the Discussion & 2 & 1 & - & $\mathbf{3}$ \\
\hline
\end{tabular}

The most frequent descriptor in teaching presence was related to facilitating discourse, followed by direct instruction. Prevalence of teaching presence for facilitating discourse was clustered most heavily on encouraging, acknowledging or reinforcing students' contributions. Within the direct instruction domain, there were more posts that focus on discussion on specific issues and injecting knowledge from diverse sources. The posts related to instructional design and organization domain were moderate in number. There were no posts for 'designing methods'(TPA2) 'utilizing medium effectively'(TPA4), 'setting climate for learning' (TPB4), 'assess the efficacy of the process' (TPB6) and 'present content and questions'(TPC1).

\section{Cognitive Presence}

Table 5 illustrates the distribution of cognitive presence for Tasks 1,2 and 3.

Table 5

Numerical Distribution of Cognitive Presence for Tasks 1, 2 and 3

\begin{tabular}{lllllc}
\hline Codes & Descriptors & Task 1 & Task 2 & Task 3 & Total \\
\hline CPA & Triggering event & & & & \\
CPA1 & Recognizing the Problem & 42 & 21 & 26 & $\mathbf{8 9}$ \\
CPA2 & Sense of Puzzlement & 4 & 1 & 1 & $\mathbf{6}$ \\
CPB & Exploration & & & & \\
\hline & & & & (continued)
\end{tabular}




\begin{tabular}{lllllc}
\hline Codes & Descriptors & Task 1 & Task 2 & Task 3 & Total \\
\hline CPB1 & Diverse within Online Communication & - & - & - & - \\
CPB2 & Divergence within Single Message & - & - & - & - \\
CPB3 & Information Exchange & 20 & 3 & 4 & $\mathbf{2 7}$ \\
CPB4 & Suggestion for Consideration & 3 & 4 & 2 & $\mathbf{9}$ \\
CPB5 & Brainstorming & 9 & 5 & 4 & $\mathbf{1 8}$ \\
CPB6 & Leap to Conclusions & 1 & - & - & $\mathbf{1}$ \\
CPC & Integration & & & & \\
CPC1 & Convergence among Group Members & - & - & - & - \\
CPC2 & Convergence within a Single Message & 1 & - & - & $\mathbf{1}$ \\
CPC3 & Connecting Ideas, Synthesis & - & 2 & 2 & $\mathbf{4}$ \\
CPC4 & Creating Solutions & 58 & 55 & 28 & $\mathbf{1 4 1}$ \\
\hline
\end{tabular}

Table 5 shows the numerical distribution of cognitive presence. It is quite clear that the integration phase had the most posts. Creating solutions was the most common descriptor within the integration phase. The next common phase was the triggering event. The exploration phase had the least number of posts. In the exploration phase, there were no posts at all for descriptors related to 'divergence within online communication'(CPB1) and 'divergence within a single message'(CPB2). In the integration phase, there was only one post for the descriptor related to convergence among group members. The resolution phase was in the written assignment where students made the changes based on their interactions to improve their narrative essays.

\section{Emerging Patterns}

According to Le (1999) research can be considered as an excursion. He explains that the entire meaning of the study can only be achieved when the excursion ends. There is no promise or assurance that the excursion will follow what was planned at the initial stage. Only when the research ends, the researcher realises the complete scenario of the whole journey. Following this line of thought, the present research did provide additional findings that emerged as supplementary findings. In terms of sequencing, the phases of cognitive presence namely triggering, exploration, integration and resolution phases for narrative writing in the Malaysian context took 
a distinctive pattern. The online interaction patterns for cognitive presence were analysed according to the framework of single, dual and triple phases based on the tasks given to the students.

This is the uniqueness of the use of the CoI model to explore interactions in a new setting which involved Malaysian students learning to write narrative essays. Single, dual and triple phases were created by the researchers for this study. The discussion is centred on selected issues or events of language use. As a qualitative study with a large amount of data the results were rich. For this study, the researchers intend to only discuss certain events to show the distinctive pattern that occurred. The phases created for this study are illustrated in Table 6.

Table 6

Cognitive Presence for this Study

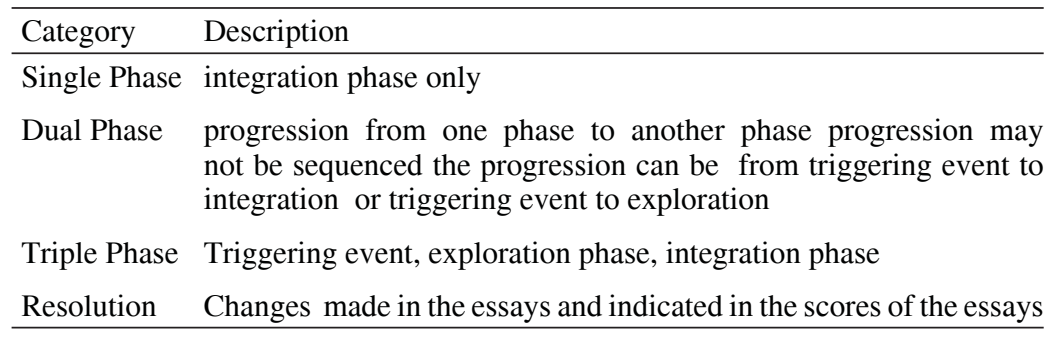

The single phase took place when students and teacher were involved in creating solutions on grammatical aspects and sentence structures. The students basically made the changes as indicated in the interactions. There were instances where corrections were made and the comments indicated the problems as in "it is past participle verb form" (Valentini Belbo) and "makes me feel embarrassing = made, past tense" (Joyce Chee). The interactions exhibited that the teacher basically directed the interactions to the integration phase by creating the solutions. Table 7 illustrates the cognitive presence related to the single phase.

There were a considerable number of interactions that involved two phases. In most interactions related to the dual phase, the triggering event involved the students and the integration phase involved the teacher. The interactions were stalled at the integration phase when the teacher confirmed certain ideas. 
Table 7

Online Interaction pattern of Cognitive Presence Involving Single Phase related to Sentence Structures and Grammatical Errors

\begin{tabular}{|c|c|c|c|}
\hline $\mathrm{CPC}$ & Integration & & \\
\hline \multirow[t]{9}{*}{ C4 } & Creating & 筃垔 & $\begin{array}{l}\text { Valentini Belbo *that had happened } \\
\text { June } 29 \text { at 10:32pm via mobile - Like }\end{array}$ \\
\hline & & & $\begin{array}{l}\text { Joyce Chee as I had expected. = as I expected or as what I had } \\
\text { expected } \\
\text { June } 29 \text { at } 10: 40 \mathrm{pm} \text { - Like ' } \lesssim 1\end{array}$ \\
\hline & & KEEP & $\begin{array}{l}\text { Valentini Belbo without long thinking - without much thinking } \\
\text { June } 29 \text { at } 10: 34 \mathrm{pm} \text { via mobile - Like ' } 1\end{array}$ \\
\hline & & KËP & $\begin{array}{l}\text { Valentini Belbo it is a past participle verb form } \\
\text { June } 29 \text { at } 10: 36 \mathrm{pm} \text { via mobile - Like }\end{array}$ \\
\hline & & & $\begin{array}{l}\text { Nanthini Maniam Monster KBlue... "I stunt there for a few } \\
\text { seconds." is wrong. It is supposed to be "I was stunt there for a } \\
\text { few seconds." Not only that..." strange person" is wrong. It is } \\
\text { "stranger" } \\
\text { July } 4 \text { at } 9: 57 \mathrm{pm} \text { - Like . } 32\end{array}$ \\
\hline & & है & $\begin{array}{l}\text { Deer Tommy "juse a stone's throw away" } \rightarrow \text { just?? } \\
\text { June } 28 \text { at } 10: 33 \mathrm{pm} \text {. Unlike ' } \measuredangle 2\end{array}$ \\
\hline & & 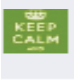 & $\begin{array}{l}\text { Valentini Belbo We have been best friends since } 7 \text { years old..Nt } \\
\text { we are best friends since } 7 \text { years old.. } \\
\text { June } 29 \text { at } 4: 30 \mathrm{pm} \text {. Unlike } \cdot 33\end{array}$ \\
\hline & & 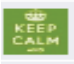 & $\begin{array}{l}\text { Valentini Belbo and...he seldom smiles to others.. } \\
\text { June } 29 \text { at } 4: 32 \mathrm{pm} \text {. Like }\end{array}$ \\
\hline & & & $\begin{array}{l}\text { Joyce Chee makes me feel embarrassing, = made, past tense } \\
\text { June } 29 \text { at } 10: 20 \mathrm{pm} \text {. Like } \cdot \Omega 1\end{array}$ \\
\hline
\end{tabular}

Table 8

Online Interaction Pattern of Cognitive Presence for the Event of "Can not or Cannot"

\begin{tabular}{|c|c|c|}
\hline$\overline{\mathrm{CPA}}$ & $\begin{array}{l}\text { Triggering } \\
\text { Event }\end{array}$ & Example \\
\hline A1 & $\begin{array}{l}\text { Recognizing } \\
\text { the Problem }\end{array}$ & 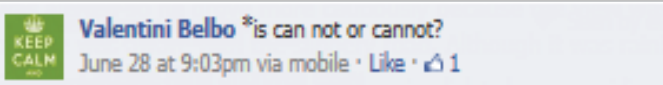 \\
\hline СРC & Integration & \\
\hline $\mathrm{C} 4$ & $\begin{array}{l}\text { Creating } \\
\text { Solutions }\end{array}$ & $\begin{array}{l}\text { Wanthini Maniam Valentini Belbo...Its "CANNOT"...CAN NOT is } \\
\text { wrong } \\
\text { July } 4 \text { at 9:31pm - Like }\end{array}$ \\
\hline
\end{tabular}

In Tables 8-9 at the triggering event phase, the students presented and highlighted their problems. For example, the students presented their doubts about the use of "can not or cannot" (Valentini Belbo, Table 8) and "how can handling obedient students a challenging job for $u$ ?" (Monster Kblue, Table 9). The teacher immediately cleared their doubts by giving the solutions to their problems. She stated 
that "Its "CANNOT"... CAN NOT is wrong" (Table 8), "You are right... how can handling obedient students a challenging job?... It is supposed to be disobedient" (Table 9).

Table 9

Online Interaction Pattern of Cognitive Presence for the Event of "Obedient students"

\begin{tabular}{|c|c|c|}
\hline CPA & Triggering Event & Example \\
\hline A1 & $\begin{array}{l}\text { Recognizing the } \\
\text { Problem }\end{array}$ & $\begin{array}{l}\text { Monster KBlue hw can handling obedient students a challenging } \\
\text { job for u? } \\
\text { June } 29 \text { at } 10: 28 \mathrm{pm} \text { - Unlike ' } 2 \mathrm{2}\end{array}$ \\
\hline CPC & Integration & \\
\hline $\mathrm{C} 4$ & $\begin{array}{l}\text { Creating } \\
\text { Solutions }\end{array}$ & $\begin{array}{l}\text { Nanthini Maniam Monster KBlue You are right...how can handling } \\
\text { obedient students a challenging job?.....It is supposed to be } \\
\text { disobedient } \\
\text { July } 3 \text { at 11:38pm - Like · B } 1\end{array}$ \\
\hline
\end{tabular}

Tables 10-11 describe the interactions involving triple phases. The discussion for the events is provided below. These interactions triggered fruitful discussions and debates with their teacher and peers. Students were encouraged to reflect and make tentative decisions on how to make certain changes in their essays. For example, in the event related to the "wind sound"(Table 10), the students were engaged in the interactions related to the exploration phase. Students were basically brainstorming and exchanging information to clear their doubts. They were developing and justifying each others' ideas on the use of "whooping" for the sound of the wind. In this process, they were able to learn the use of many words such as "hooting", "chirping" and "whooping" according to the context. Finally, the interaction ended when the teacher confirmed certain ideas put forward by the students in this phase. Similar interactions were also found in the event related to "experienced or experience" (Table 11).

The teacher's involvement in the integration phase was to highlight certain ideas that could be considered by the students and to make the corrections in their essays written after the interactions in the collaborative learning environment. This was evident when they made the necessary changes in their essays written after the online interactions. 
Table 10

Online Interaction Pattern of Cognitive Presence for the Event of "Wind Sound"

\begin{tabular}{|c|c|c|c|}
\hline CPA & $\begin{array}{l}\text { Triggering } \\
\text { Event }\end{array}$ & & Example \\
\hline $\mathrm{A} 1$ & $\begin{array}{l}\text { Recognizing the } \\
\text { Problem }\end{array}$ & 2. 30 . & $\begin{array}{l}\text { Catelite Nina } \\
\text { Is whooping suitable for describing the wind sound? } \\
\text { Like : Comment - Unfollow Post ? June } 30 \text { at 7:55pm }\end{array}$ \\
\hline CPB & Exploration & & \\
\hline \multirow[t]{3}{*}{ B3 } & \multirow[t]{3}{*}{$\begin{array}{l}\text { Information } \\
\text { exchange }\end{array}$} & & $\begin{array}{l}\text { Nanthini Maniam Whooping means....A loud cry excitement, A } \\
\text { shout uttered by a hunter or warrior, A hooting cry, as of a bird and } \\
\text { sound whooping cough. } \\
\text { July } 2 \text { at } 6: 17 p m \text { - Like. } \Delta 3\end{array}$ \\
\hline & & & 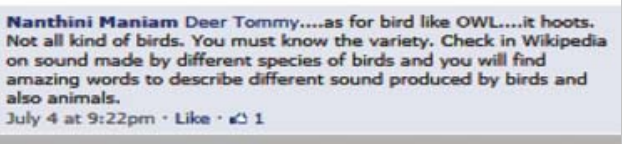 \\
\hline & & है & $\begin{array}{l}\text { Deer Tommy As of a bird? How to use whooping in this? } \\
\text { July } 2 \text { at } 6: 20 \mathrm{pm} \text {. Like }\end{array}$ \\
\hline \multirow[t]{2}{*}{ B5 } & \multirow[t]{2}{*}{ Brainstorming } & $2 \pi$ & $\begin{array}{l}\text { Catelite Nina i think bird use chirping sound is more surrable } \\
\text { July } 6 \text { at } 8: 05 \text { pm - Unlike. - } \Delta 2\end{array}$ \\
\hline & & $\overrightarrow{\mathrm{C}_{3}}$ & $\begin{array}{l}\text { Deer Tommy For me, It is betrer to describe the wind "cool } \\
\text { breeese" than Using whooping? } \\
\text { July } 1 \text { at } 7: 13 \mathrm{pm} \text { - Like - } \Delta 1\end{array}$ \\
\hline CPC & Integration & & \\
\hline $\mathrm{C} 4$ & $\begin{array}{l}\text { Creating } \\
\text { Solution }\end{array}$ & & $\begin{array}{l}\text { Nanthini Maniam Catelite Nina...yes you are right. Hooting can } \\
\text { also be used to describe an eerie situation. } \\
\text { July } 7 \text { at } 11: 21 \mathrm{pm} \text { - Like - } \omega 11\end{array}$ \\
\hline
\end{tabular}

The progression from the first phase to the fourth phase (final phase) is not shown in the following description as the fourth phase (resolution) is only evident in the students' final narrative essays when corrections were completed after interactions. The changes made in the essays are considered the resolution phase. Students have made the changes and this is indicated in their narrative writing scores which were much higher for essays after interactions than before interactions.

The letters $\mathrm{O}, \mathrm{C}, \mathrm{L}, \mathrm{V}, \mathrm{M}$ and $\mathrm{T}$ in Table 12 refer to organization, content, language, vocabulary, mechanics and total respectively. The students are labelled as S1(Deer Tommy), S2(Valentini Belbo),S3(Monster Kblue),S4(Peonny Moon),S5 (Joyce Chee) and (S6) Catelite Nina. 
Table 11

Online Interaction Pattern of Cognitive Presence for the Event of "Experience or experienced"

\begin{tabular}{|c|c|c|}
\hline CPA & Triggering Event & Example \\
\hline A1 & $\begin{array}{l}\text { Recognizing tl } \\
\text { Problem }\end{array}$ & $\begin{array}{l}\text { Joyce Chee During my duty, I have experience many interesting } \\
\text { things, = I experienced, it's already past, have experience is in } \\
\text { present.. have experienced is also a bit weird, ithink maybe can } \\
\text { put had experienced.. Premani Supramaniam which one is more } \\
\text { suinable? } \\
\text { June } 29 \text { at } 10: 19 \mathrm{pm} \text {. Like }\end{array}$ \\
\hline CPB & Exploration & \\
\hline \multirow[t]{3}{*}{ B4 } & $\begin{array}{l}\text { Suggestion for } \\
\text { considerations }\end{array}$ & $\begin{array}{l}\text { Peony Moon had experienced? i tot we have to put original word } \\
\text { after had? or have i imb wrong?? } \\
\text { June } 30 \text { at } 5: 56 \mathrm{pm} \text {. Like - } \angle 32\end{array}$ \\
\hline & & $\begin{array}{l}\text { Nanthini Maniam Joyce Chee It is better to write "During my } \\
\text { duty, I had experience..." } \\
\text { July } 3 \text { at } 11: 32 \mathrm{pm} \text { - Like }\end{array}$ \\
\hline & & $\begin{array}{l}\text { Joyce Chee Premani Supramaniam after had should put root } \\
\text { word ? } \\
\text { July } 4 \text { at 12:15am - Like }\end{array}$ \\
\hline B5 & Brainstorming & $\begin{array}{l}\text { Joyce Chee Peony Moon had experienced is past prefect...i think } \\
\text { you remembered wrong.. } \\
\text { July } 1 \text { at 9:57pm - Like }\end{array}$ \\
\hline CPC & Integration & \\
\hline $\mathrm{C} 4$ & Creating Solut & $\begin{array}{l}\text { Nanthini Maniam Joyce Chee... Oh sorry, there is a typo } \\
\text { error.... after had... it should be participle form....Its should be HAD } \\
\text { EXPERIENCED. } \\
\text { July } 4 \text { at 3:12pm - Like - } \omega 1\end{array}$ \\
\hline
\end{tabular}

Table 12

Students' Average Scores for Narrative Writing Task 1

\begin{tabular}{ccccccccccccc}
\hline & \multicolumn{11}{c}{ AVERAGE SCORES } \\
\cline { 2 - 12 } & \multicolumn{11}{c}{ BEFORE INTERACTIONS } & \multicolumn{1}{c}{ AFTER INTERACTIONS } \\
\cline { 2 - 12 } & O & C & L & V & M & T & O & C & L & V & M & T \\
\hline S1 & 15 & 16 & 18 & 11 & 6 & $\mathbf{6 6}$ & 15 & 16 & 19 & 12 & 6 & $\mathbf{6 8}$ \\
S2 & 14 & 15 & 17 & 13 & 6 & $\mathbf{6 5}$ & 14 & 15 & 18 & 15 & 6 & $\mathbf{6 8}$ \\
S3 & 15 & 15 & 22 & 15 & 6 & $\mathbf{7 4}$ & 15 & 16 & 23 & 16 & 6 & $\mathbf{7 6}$ \\
S4 & 14 & 14 & 18 & 13 & 6 & $\mathbf{6 5}$ & 14 & 14 & 20 & 15 & 6 & $\mathbf{6 9}$ \\
S5 & 14 & 14 & 16 & 14 & 6 & $\mathbf{6 4}$ & 14 & 13 & 17 & 16 & 6 & $\mathbf{6 5}$ \\
\hline S6 & 17 & 18 & 23 & 16 & 6 & $\mathbf{8 0}$ & 17 & 18 & 24 & 17 & 6 & $\mathbf{8 2}$ \\
\hline
\end{tabular}


Table 13

Students' Average Scores for Narrative Writing Task 2

\begin{tabular}{lcccccccccccc}
\hline & \multicolumn{11}{c}{ AVERAGE SCORES } \\
\cline { 2 - 12 } & \multicolumn{11}{c}{ BEFORE INTERACTION } & \multicolumn{1}{c}{ AFTER INTERACTIONS } \\
\cline { 2 - 12 } & O & C & L & V & M & T & O & C & L & V & M & T \\
\hline S1 & 15 & 16 & 15 & 15 & 6 & $\mathbf{6 7}$ & 15 & 16 & 17 & 16 & 6 & $\mathbf{7 0}$ \\
S2 & 14 & 15 & 15 & 14 & 6 & $\mathbf{6 4}$ & 14 & 15 & 16 & 14 & 6 & $\mathbf{6 5}$ \\
S3 & 15 & 15 & 17 & 14 & 6 & $\mathbf{6 7}$ & 15 & 15 & 18 & 15 & 6 & $\mathbf{6 9}$ \\
S4 & 15 & 16 & 18 & 14 & 6 & $\mathbf{6 9}$ & 15 & 16 & 19 & 15 & 6 & $\mathbf{7 1}$ \\
S5 & 15 & 16 & 19 & 15 & 6 & $\mathbf{7 1}$ & 15 & 15 & 20 & 16 & 7 & $\mathbf{7 3}$ \\
\hline S6 & 17 & 18 & 24 & 18 & 6 & $\mathbf{8 3}$ & 17 & 18 & 25 & 18 & 6 & $\mathbf{8 4}$ \\
\hline
\end{tabular}

Table 14

Students' Average Scores for Narrative Writing Task 3

\begin{tabular}{|c|c|c|c|c|c|c|c|c|c|c|c|c|}
\hline & \multicolumn{12}{|c|}{ AVERAGE SCORES } \\
\hline & \multicolumn{6}{|c|}{ BEFORE INTERACTION } & \multicolumn{6}{|c|}{ AFTER INTERACTION } \\
\hline & $\mathbf{O}$ & $\mathbf{C}$ & $\mathbf{L}$ & $\mathbf{V}$ & M & $\mathbf{T}$ & $\mathbf{O}$ & $\mathbf{C}$ & $\mathbf{L}$ & $\mathbf{V}$ & $\mathbf{M}$ & $\mathbf{T}$ \\
\hline S1 & 15 & 15 & 20 & 16 & 7 & 73 & 15 & 15 & 20 & 16 & 7 & 73 \\
\hline S2 & 15 & 15 & 17 & 15 & 7 & 69 & 15 & 15 & 18 & 16 & 7 & 71 \\
\hline S3 & 15 & 14 & 17 & 15 & 7 & 68 & 15 & 15 & 18 & 16 & 7 & 71 \\
\hline S4 & 15 & 15 & 16 & 16 & 7 & 69 & 15 & 15 & 16 & 16 & 7 & 69 \\
\hline S5 & 14 & 15 & 15 & 14 & 7 & 65 & 14 & 15 & 15 & 14 & 7 & 65 \\
\hline S6 & 16 & 18 & 21 & 19 & 7 & 81 & 16 & 18 & 21 & 19 & 7 & 81 \\
\hline
\end{tabular}

\section{DISCUSSION}

The three presences were identified in this study. In terms of number, the most frequent number of posts occurred for cognitive presence, followed by social presence and teaching presence. Certain descriptors were not found in this study. In the social presence domain the descriptors related to 'continuing a thread' and 'referring explicitly to other messages' were not found. These were not mainly collaborative per se to jointly complete a group task. 
Vocatives were not applicable as the pseudonym appears in their posts. Such features were not found in the online forum from where the CoI model originated. In cognitive presence, 'divergence with online communication' and 'divergence within single message' were not found. Students were probably not engaged in deep discussion. In teaching presence, descriptors related to 'utilizing medium effectively' and 'setting climate for learning' were not necessary as students were interacting well. 'Establishing netiquette' was also not necessary as students were not interacting in an annoying way. 'Seeking to reach consensus' was not relevant in this context. The group was not required to reach a consensus because the students were to write the essays on their own. There was also an overlap of meanings in certain descriptors for 'present content and questions' and 'designing methods'. In other words, there were no clear cut definitions for these two descriptors.

This study was able to identify the integration and resolution phases. It appeared that students were able to achieve the triggering and exploration phases and leap-frogging to integration or resolution phases. However, this did not mean that the students had achieved the higher order thinking level as suggested by Garrison et al. (2000). According to their CoI model, students are able to achieve higher order thinking if they are able to reach the resolution phase. The definition of lower order thinking and higher order thinking in cognitive presence as suggested by Garrison et al. is not applicable in the teaching of narrative writing for the participants of this study. This is because students were able to achieve the resolution phase without engaging in all the four phases of cognitive presences.

The contradictory findings in the present study may be due to the nature of the task. Arbaugh, Bangert and Cleveland-Innes (2010) suggest that the nature and level of the course content determine the higher order thinking skills in cognitive presence. In this study, the narrative writing task is assigned to the secondary school students. Furthermore, the narrative writing task demands creative thinking and not so much of critical thinking. Creative writing is related to originality, imagination and non-judgmental actions whereas critical thinking is analytical, judgmental, selective, accurate, careful and problem solving (Lipman, 2003; Lewis \& Smith, 1993). However, critical thinking was found to take place in this study when students 
were evaluating, comparing and contrasting how certain ideas, materials, choice of vocabulary should be used in composing the essays.

This study differs from Garrison et al.'s online forum discussion since the narrative writing task was more related to the domain of creative thinking rather than critical thinking. These phases in the ONWP were related to creative writing leading to critical thinking. For the above reasons, it seemed possible that students did not go through the four phases of cognitive presence to achieve deep and meaningful learning.

There were patches of discussion in the interactions which can be categorized as critical thinking but the teacher 'exerted' her online teacher-centeredness by intervening and providing answers, confirming, reaffirming, all of which resulted in closing down interactions. The online teacher-centeredness comes into play moving from triggering event to resolution. Therefore, the teacher's role in this online learning to a certain extent can be seen as a medium "to complete a particular task, rather than an opportunity to engage in rich discussion and debate with their peers and instructors" as proposed by Hara, Bonk and Angeli (2000, p. 148). However, with the effort of the teacher there could be opportunities for students to move to a higher level of thinking related to analyzing, evaluating and creativity. For example, in this study, an in-depth discussion could have been conducted in issues related to grammatical and sentence structures. The effort of scaffolding to transcend students' thinking was not sufficiently provided by the teacher when facilitating the students online. This can be further investigated in future research.

Previous studies often indicated that students were not reaching the integration and resolution phases that were considered as the higher order thinking skills (Garrison \& Vaughan, 2008). Archer (2010) highlighted that a higher level of cognition is not achieved since "we have been looking for these phases in the wrong place" (p. 69). This study shows that the analysis of the interactions leading to writing task completion rather than observation of an online discussion has provided a tangible evidence of the higher cognitive level. Thus, this finding can be considered unique when compared to previous studies related to the $\mathrm{CoI}$ model as the resolution phase was evaluated based on the amendments made by the students in the improved essays. 


\section{CONCLUSION}

Previous studies on the utilization of the CoI model were very much related to online discussions involving forums on critical issues. Thus, the component of critical thinking is viewed as an important aspect of discussion in the cognitive presence of the CoI model. However, the present study is based on the task of narrative writing. The genre of narrative writing can be categorized under the domain of creative writing. As such, the identification of interactions involving critical thinking becomes problematic. Previous studies used discussions of critical issues based on topics that have inclinations towards critical thinking. The use of elements related to critical thinking can only be identified, seen and discussed minimally in this study. Moving on from here, it is suggested that the component of creative writing should be integrated in future discussion of this model. Being online to fulfil wide-ranging tasks does not only involve critical thinking but other types of thinking.

This study is considered different from previous studies as it explored the experience of teachers and ESL students in the Malaysian ESL context. Most of the previous studies related to the CoI model were centred on undergraduate students in institutions of higher education (Toth, Amrein-Beardsley \& Foulger, 2010). This study has placed the model in a new setting. As this study was conducted with a small group of students in a very specific setting, more research need to be conductedindiverse Malaysianschool settingsusinglargersamplesfor generalization purposes and to investigate the robustness of the findings.

There are several important pedagogical implications stemming from this study for the ESL learners and teachers in the Malaysian context. Teachers need to be trained to facilitate the teaching of narrative writing properly. Efforts can be made by the teacher to encourage critical thinking in creative writing. Teachers should realise that there is more to teach in writing than just making corrections. The final essay should not only focus on the correcting of misspelt words, grammar and sentence structures. There is a need for teachers and students to change their mindset to maximize the benefits of the ONWP in web-based teaching and learning. 


\section{ACKNOWLEDGEMENTS}

This work is supported by USM short term grant 304/PGURU/631304

\section{REFERENCES}

Annamalai, N., \& Tan, K.E(2014). Social presence of the community of inquiry (CoI) model on an online narrative writing platform via Facebook. Malaysian Journal of ELT Research, 10 (2), 1-18. Arbaugh, J. B., Bangert, A., \& Cleveland-Innes, M. (2010). Subject matter effects and the community of inquiry (CoI) framework: An exploratory study. The Internet and Higher Education, 13(1), 37-44.

Akyol,Z., \& Garrison, D. R. (2008). The development of a community of inquiry overtime in an online course: Understanding the progression and integration of social, cognitive and teaching presence. Journal of Asynchronous Learning Networks, 12(3), 3-22.

Anderson, T., Rourke, L., Garrison, D. R., \& Archer, W. (2001). Assessing teacher presence in a computer conferencing context. Journal of Asynchronous Learning Networks, 5(2), 1-17.

Archer, W. (2010). Beyond online discussions: Extending the community of inquiry framework to entire courses. The Internet and Higher Education, 13(1-2), 69.

Babaii, E., \& Yazdanpanah, Z. (2010). Toward self-expression in L2 classrooms: The effect of explicit teaching of story structures on EFL learners' narrative ability. Asian EFL Journal, 44, 4-19.

Bagley, C., \& Hunter, B. (1992). Restructuring, constructivism, and technology: Forging a New Relationship. Educational Technology, 32(7), 22-27.

Batruff, E., \& Headley, S. (2009). Using the community of inquiry model (2001) to evaluate online courses in teacher education. In Gibson et al. (Eds.) Proceedings of Society for Information Technology Education International Conference 2009 (pp.795-800). Chesapeake: AACE.

Clark, R. E. (2001). Learning from Media: Arguments analysis and evidence. Greenwich, CT: Information Age.

Dewey, J. (1916). Democracy and education. New York: McMillan. Garrison, D. R., Anderson T., \& Archer W. (2000). Critical inquiry in a text based environment: Computer conferencing in higher education . Internet and Higher Education, 11(2), 1-14. 
Garrison, D. R., \& Anderson, T. (2003). E-learning in the $21^{\text {st }}$ century: A framework for research and practice. New York: Routledge Falmer.

Garrison, D. R., Cleveland-Innes, M., \& Fung, T. S. (2010). Exploring causal relationships among teaching, cognitive and social presence: Student perceptions of the community of inquiry framework. The Internet and Higher Education, 13(1), 31-36.

Garrison, D. R., \& Cleveland-Innes, M. (2005). Facilitating cognitive presence in online learning: Interaction is not enough. American Journal of Distance Education, 19(3), 133-148.

Garrison, D. R., \& Arbaugh, J. B. (2007). Researching the community of inquiry framework: Review, issues and future directions. The Internet and Higher Education, 10, 157-172.

Garrison, D. R., \& Vaughan, N. (2008). Blended learning in higher education: Framework, principles, and guidelines. San Francisco: Jossey-Bass.

Hara, N., Bonk, C. J., \& Angeli, C. (2000). Content analysis of online discussion in an applied educational psychology course. Instructional Science, 28(2), 115-152.

Kear, K. (2010). Social presence in online learning communities. Proceedings of the 7th International Conference on Networked learning 2010. Aalborg, Denmark, 3-4 May 2010

Kigotho, M. (2002). Relating the structure of the oral narrative to literacy. Retrieved 13 March 2010, from http://www.aare. edu.au/02pap/kig02111.htm

Labov, W. \& Waletzky, J. (1967). Narrative analysis, In J. Helm (Eds.), Essays on verbal and visual. Seattle: Washington Press. Reprinted in Journal of Narrative and Life History 7:3-38. Lewis, A., \& Smith, D. (1993). Defining for higher order thinking. Theory into Practice, 32(3), 131-137.

Lipman, M. (2003). Thinking in education (2nd ed.). Cambridge: Cambridge University Press.

Luebeck, J. L., \& Bice, L. R. (2005). Online discussion as a mechanism of conceptual change among mathematics and science teachers. Journal of Distance Education, 20(2), 21-39.

Le, Q. (1999). The development and evaluation of a multi-mediabased instruction package on scientific genre. Western Australia: Curtin University.

Kaufman, A. S., \& Kaufman, N. L. (2005). Essentials of reseach design and methodology. New Jersey: John Wiley \& Sons. 
Kigotho, M. (2002). Relating the structure of the oral narrative to literacy. Retrieved 13 March 2010, from http://www.aare. edu.au/02pap/kig02111.htm

Malaysian Education Blueprint 2013-2025. (2013). Ministry of Education, Malaysia.

Patton, M. Q. (2002). Qualitative research \& evaluation methods: Thousand Oaks: Sage Publications.

Pawan , F. T., Paulus, M., Yalcin, S., \& Ching, C. (2003). Online learning: Patterns of engagement and interaction among inservice teachers. Language Learning Technology, 7(3), 119-1.

Perez-Sabater., \& Rising, B (2009). Short and long term retention and student motivation using active learning and simulation techniques. Learn to Game, Game to learn Proceedings of the 40th Conference of the Simulation and gaming Association.

Pope, C. (2000). Analysing qualitative data. Retrieved 14 March 2011, from http://www.bmj.com/content/320/7227/114.extract

Seale, C. F. (1999). The quality of qualitative research. London: Sage.

Shea, P., Hayes, S., \& Vickers, J. (2010). Online instructional effort measured through the lens of teaching presence in the community of inquiry framework: A re-examination of measures and approach. The International Review of Research in Open and Distance Learning, 11(3), 127-154.

Stirling, L., Barrington, G., \& Douglas, S. (2007). Progression in narrative ability: A case study comparing successive written and oral retellings of three little pigs' by a child with autism. Paper presented in Biennal Autism Conference, The Gold Coast, Australia.

Toth, M., Amrein-Beardsley, A., \& Foulger, T. (2010). Changing delivery methods, changing practices: Exploring instructional practices in face-to-face and hybrid courses. Journal of Online Learning and Teaching, 6(3), 617-633.

Tribble, C. (1996). Writing. Oxford: University Press.

Vaughan, N. D., \& Garrison, D. R. (2005). Creating cognitive presence in a blended faculty development community. Internet and Higher Education, 8, 1-12.

Vygotsky, L. (1978). Mind in society: The development of higher psychological processes. Cambridge, Mass: Harvard University Press. 